\title{
PROGNOSTIC FACTORS IN PATHOLOGIC FRACTURES SECONDARY TO METASTATIC TUMORS
}

\author{
Douglas Kenji Narazaki, Carlos Coelho de Alverga Neto, André Mathias Baptista, \\ Marcelo Tadeu Caiero Olavo Pires de Camargo
}

Narazaki DK, Alverga Neto CC, Baptista AM, Caiero MT, Camargo OP. Prognostic factors in pathologic fractures secondary to metastatic tumors. Clinics. 2006;61(4):313-20.

OBJECTIVE: Pathological fractures caused by metastases sharply decrease the quality of life and increase mortality rates for patients with malignant neoplasias. Orthopedic advances in osteosynthesis and endoprosthesis have been beneficial in the prevention and treatment of such fractures. The objective of our study was to determine which prognostic factors for pathologic fractures treated in our Service were significant.

METHOD: This was a retrospective study enrolling 112 patients treated for pathologic fractures secondary to metastatic tumors between April 1994 and December 2004 in our Service. Patients were analyzed according to sex, age, bone metastasis site, visceral metastases, origin of primary tumor, treatment type, serum hemoglobin, and survival.

RESULTS: The most affected site was the femur (44\%), the most frequent primary tumor was breast cancer (25\%); the most frequently employed surgical treatment was unconventional endoprosthesis $(66 \%)$. Sex, age, primary tumor, site affected, nonbone metastasis, and clinical versus surgical treatment variables were not good predictors for survival. The only significant predictor was the type of surgery employed. Patients who received an endoprosthesis presented a worse prognosis (21.6 months) than patients undergoing osteosynthesis (47.8 months).

CONCLUSION: Patients undergoing osteosynthesis, with a less morbid surgical technique and earlier rehabilitation, had longer survival times than patients who received endoprostheses. Our case series is similar to international ones, where the most frequent primary tumor is breast tumor, followed by tumors of undetermined origin, prostate, and lung tumors.

KEYWORDS: Pathological fractures. Neoplasia. Metastasis. Prognosis. Surgery.

\section{INTRODUCTION}

According to data issued by the Brazilian Ministry of Health in 2002, neoplasias are the second most frequent, well-defined cause of mortality in Brazil, the first being cardiocirculatory system diseases.

Metastatic disease is the main cause of death among cancer patients, the third most common site of metastases being the bone, after liver and lungs. Breast, lung, thyroid, prostate, and kidney tumors are most likely to metastasize

Department of Orthopedics and Traumatology Faculty of Medicine, University of São Paulo /SP, Brazil.

Email: olapcama@uol.com.br

Received for publication on January 16, 2006

Accepted for publication on April 19, 2006 to bone. Approximately $50 \%$ of all patients dying from cancer have bone metastases. ${ }^{1}$

New oncologic treatments available allow these patients' survival times to increase, and the oncologic orthopedist must be able to evaluate and treat the different complications secondary to bone metastases. These problems include pain, pathologic fractures, and medullary compression. ${ }^{2}$

Pathologic fractures cause a sharp decrease in the quality of life of these patients and increase their mortality. Orthopedic advances in osteosynthesis and endoprosthesis have benefited prevention and treatment of such fractures. Other beneficial adjuvant treatments include, locally, the use of cement and radiotherapy and, systemically, chemotherapy, radiotherapy, and hormone therapy. ${ }^{2-6}$

The sites that are most affected by bone metastases in- 
clude the vertebral column, hip, ribs, femur, and skull. Pathologic fractures occur in $9 \%$ to $29 \%$ of patients with bone metastases. ${ }^{7,8}$ The average survival of patients with metastatic disease secondary to breast, prostate, and lung adenocarcinoma is 34 months, 24 months, and 4 months, respectively. ${ }^{8,9}$

In bone metastases caused by renal cell carcinoma, patients with limb, not axial skeleton, injuries have longer survival times (i) when there is a disease-free interval longer than 2 years between nephrectomy and the onset of metastases, (ii) when there is a single, versus multiple, bone injury, and (iii) when there is an absence of metastasis at early disease diagnosis. ${ }^{10}$

In bone metastases secondary to breast adenocarcinoma, the only significant prognostic factors are the presence of associated visceral metastases and duration of symptoms less than 3 months, determining shorter survival. ${ }^{6,9}$

With the increase in the global survival of patients with bone metastasis, it is important to establish defined protocols for clinical and surgical approaches aiming to improve the quality of local control of the bone injury, even before the occurrence of a pathologic fracture, and to maintain such stabilization for many years.

The objective of our study was to determine the prognostic factors of pathologic fractures caused by metastatic tumors of various origins treated in our Service.

Determining which patients have a better prognosis is important, since this will determine the choice of surgical treatment type. Patients with a better expectation of survival require a more aggressive treatment with wide and marginal resection of the bone tumor associated with endoprosthesis + cement or osteosynthesis + graft/cement and postoperative radiotherapy. This approach is necessary because patients with longer survival, typically greater than 2 years, present higher failure indexes of the synthetic ma-

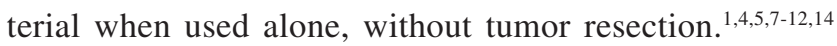
However, patients with low expectations for survival may benefit from a less aggressive, less morbid treatment with internal fixation using interlocking nails associated with adjuvant radiotherapy.

\section{METHODS}

This is a retrospective study enrolling 112 patients treated for pathologic fractures secondary to metastatic tumors between April 1994 and December 2004 in our Service. It is important to emphasize that the best inclusion criterion is histological confirmation of metastatic tumor, not merely the presence of the clinical tumor. This means that all patients undergoing conservative treatment were biopsied.
Data were obtained from medical dossiers and from a review of slices of histopathological samples from the metastatic bone tumor.

The treatment strategy for each patient depended upon factors such as the prognosis of the primary disease and the injury size and site. Therefore, metastatic tumors with poor prognosis and difficult surgical access were treated conservatively with radiotherapy and chemotherapy, while metastatic tumors with good prognosis, large injury causing instability of the segment, and easy surgical access were treated surgically.

Patients were analyzed according to sex, age, site of bone metastasis, visceral metastases, origin of primary tumor, treatment type, serum hemoglobin, and survival. $^{3,4,6,10,14,15}$

Later, a statistical study was performed using the Log Rank test, Breslow test, Tarone-Ware test, and the KaplanMeier life-table of survival, a descriptive procedure to evaluate the distribution of time-dependent variables. Thus, it is possible to compare the distribution by levels, or produce a separate analysis for each layer., ${ }^{40}$

\section{RESULTS}

Of the 112 patients studied, 53 (47\%) were men and $59(53 \%)$ were women. Figure 1 displays the age distribution of patients: 33 were aged between 50 and 59 years, while the range of the entire population was 20-88 years).

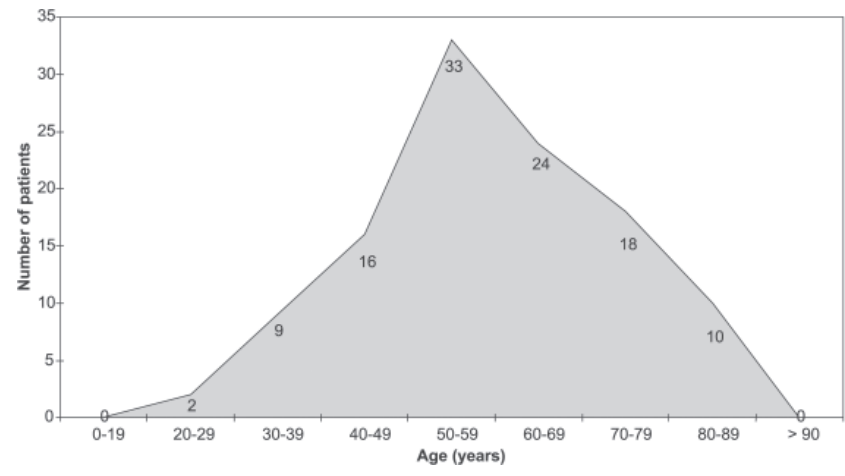

Figure 1- Distribution by age range

Primary tumors (Figure 2) were (in descending order) breast (29 patients), undetermined origin (18), prostate (16), lung (15), thyroid (7), kidney (6), collum uteri (5), esophagus (4), bowel (4), pharynx (3), myometrium (2), skin (2), stomach (1), liver (1), larynx (1), and ovary (1).

Figure 3 displays the sites of pathological fracture by segment, as follows: the lower limbs, 63 patients (47\%); spine, 40 patients (30\%); upper limbs, 16 patients $(12 \%)$; and pelvic girdle, 14 patients $(11 \%)$. In the extremities (Figure 4), the most affected site was the femur (59 patients, 


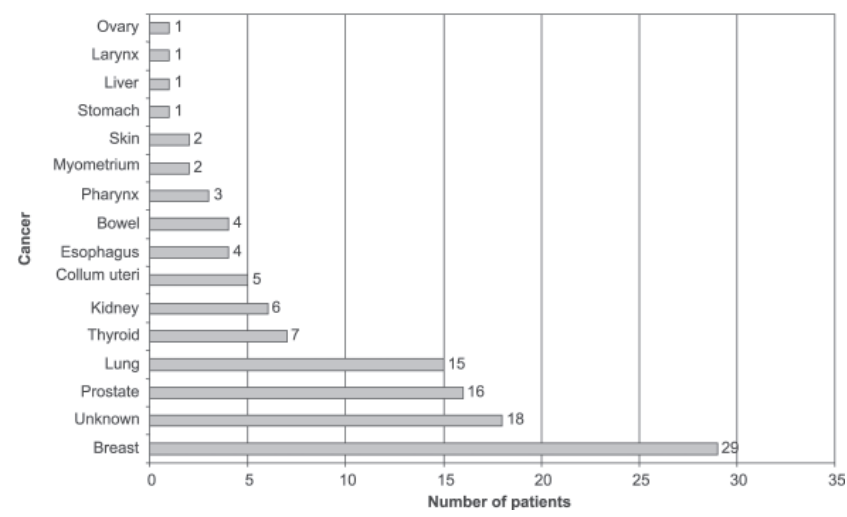

Figure 2- Distribution by primary tumor

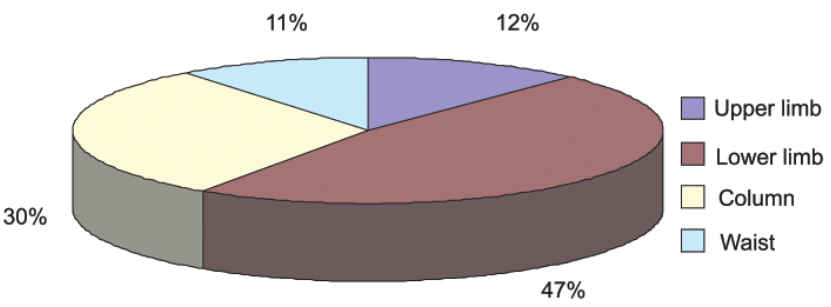

Figure 3- Distribution according to fracture site per segment

$44 \%$ ) followed by the humerus (15 patients, $11 \%)$. In the spine, the most affected portion was the lumbar area (22 patients, $17 \%)$; followed by the thorax (10 patients, $7.5 \%)$; sacrum, (10 patients, $4.5 \%)$ and cervical spine (2 patients, $1.5 \%)$. The pelvic girdle was affected in 11 patients $(8.3 \%)$ and the scapula in 2 patients $(1.5 \%)$.

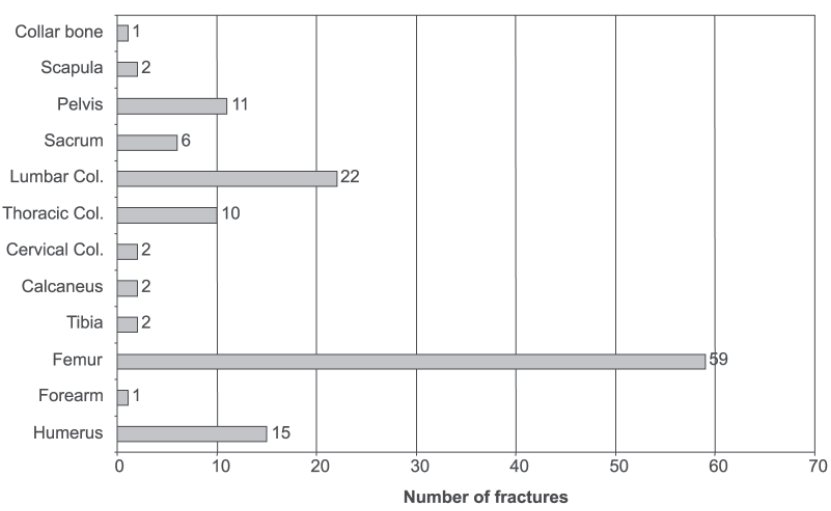

Figure 4- Distribution according to site of pathological fractures per bone.

We observed that $15 \%$ of patients presented metastases in other organs, and that the most affected site was the lung (59\%), followed by liver (15\%), as shown in Figure 5.

The treatment administered to all 112 patients ranged from clinical only to clinical and surgical. Forty-one percent were treated clinically only, with immobilizations and/or rest associated with radiotherapy, chemotherapy, hormone

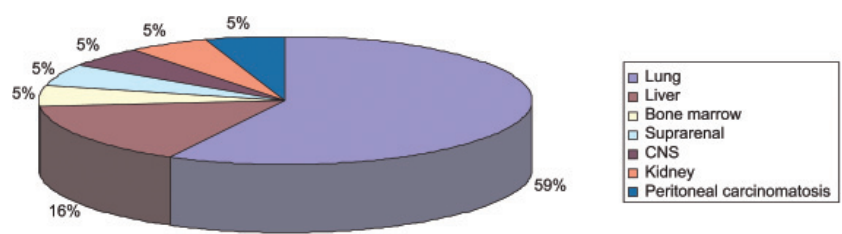

Figure 5- Distribution according to the site of non-bone metastases

therapy, and/or biphosphonates. Fifty-nine percent underwent surgical treatment in addition to clinical treatment. Regarding surgical treatment of the extremities (Figure 6), 45 patients had endoprostheses (66\%), 9 had osteosyntheses (13\%), 3 had amputations (4.4\%), 2 had external fixators (3\%), and 1 had a Girdlestone arthroplasty (1.5\%). Concerning the spine, 4 patients underwent instrumentation with the Hartshill rectangle (5.8\%), 2 had pediculate screws (3\%), and 2 had Harrington-Luque instrumentation (3\%).

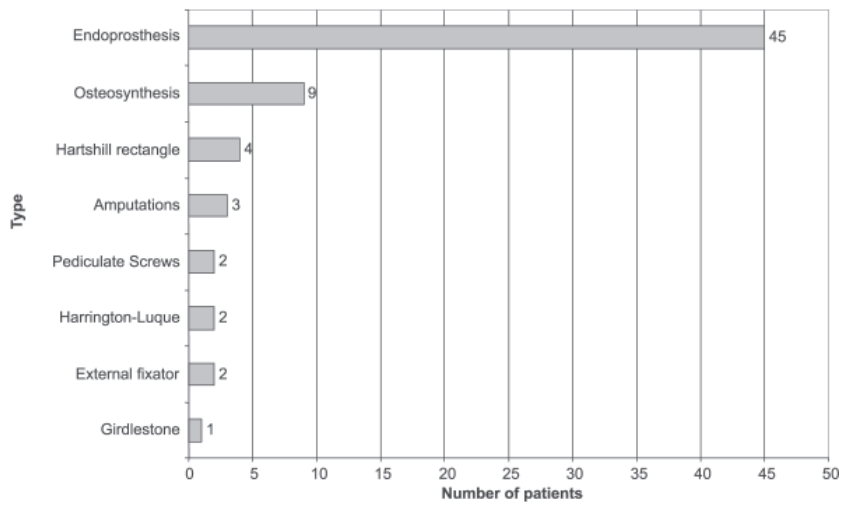

Figure 6- Distribution according to type of surgery

The endoprostheses employed were as follows: 41 partial hip, 1 total hip, 1 total knee, 1 partial shoulder, and 1 humeral diaphyseal endoprosthesis.

Serum hemoglobin laboratory tests showed that $99 \%$ of the patients presented $\mathrm{Hb}>7 \mathrm{~g} / \mathrm{dL}$.

We were able to obtain survival data for 43 out of the 112 patients: 33 had died and 10 were still alive at the end of the study. These patients were analyzed using the Kaplan-Meier life-table, a descriptive procedure to examine the distribution of time-dependant variables, which allows comparisons of the distribution by levels; or, a separate analysis for each stratum was produced.

Therefore, initially, we evaluated the distribution of survival time according to the levels of each study variable. Variables analyzed included sex, age at diagnosis, treatment type, fracture site, primary tumor, and metastases in other organs:

\section{Sex}

Of these 43 patients, 20 were men and 23 were women. Eighteen of the 20 men had died and 2 were alive. Fifteen 
of the 23 women had died and 8 were alive. The mean survival time among men was 24.2 months and among women 31.7 months; however, this was not a significant difference $(P>0.05)$. (Table 1)

Table 1- Days of survival by sex

\begin{tabular}{lcccc}
\hline Sex & Total & Alive & Dead & $\begin{array}{c}\text { Average days } \\
\text { of survival }\end{array}$ \\
\hline Female & 23 & 15 & 8 & 951 \\
Male & 20 & 18 & 2 & 725 \\
Overall & 43 & 33 & 10 & 970 \\
\hline
\end{tabular}

\section{Age at diagnosis}

The distribution by age at diagnosis shows a larger number of patients within the fifth life decade, totaling 15 patients. The age range (Table 2) with longest survival time was between 20 and 39 years (mean 90.6 months); followed by the $6^{\text {th }}$ decade ( 35.3 months), $4^{\text {th }}$ decade ( 30.3 months), $5^{\text {th }}$ decade (26.1 months), $7^{\text {th }}$ decade ( 9.5 months), and $8^{\text {th }}$ decade (5.7 months); however, this distribution did not exhibit significant differences $(P>0.05)$.

Table 2- Days of survival by age

\begin{tabular}{lcccc}
\hline Age & Total & Alive & Dead & $\begin{array}{c}\text { Average days } \\
\text { of survival }\end{array}$ \\
\hline $20 / 39$ & 3 & 1 & 2 & 2718 \\
$40 / 49$ & 7 & 5 & 2 & 911 \\
$50 / 59$ & 15 & 11 & 4 & 784 \\
$60 / 69$ & 7 & 6 & 1 & 1061 \\
$70 / 79$ & 8 & 8 & 0 & 286 \\
$80 / 89$ & 3 & 2 & 1 & 172 \\
Overall & 43 & 33 & 10 & 970 \\
\hline
\end{tabular}

\section{Initial bone injury}

The most common site of pathologic fracture (Table 3) was the femur (17 patients, 15 died and 2 are alive). The next most common were the vertebral column (15 patients, 10 died and 5 are alive); humerus (5 patients, all died); pelvic girdle ( 3 patients, 1 died and 2 are alive); and tibia ( 2 patients, 1 died and 1 is alive). The longest survival time was observed for patients with pathologic vertebral column fractures (mean 52.1 months), and the shortest survival times were observed for patients with pathologic humeral fractures (12.4 months). Again, no significant differences were found $(P>0.05)$.

\section{Primary tumor}

Regarding primary tumors (Table 4), we observed a higher incidence of breast tumors ( 9 patients, 5 dead and
Table 3- Days of survival by location of the bone metastasis

\begin{tabular}{lcccc}
\hline $\begin{array}{l}\text { Metastasis } \\
\text { location }\end{array}$ & Total & Alive & Dead & $\begin{array}{c}\text { Average days } \\
\text { of survival }\end{array}$ \\
\hline Girdle & 3 & 1 & 2 & 843 \\
Spine & 15 & 10 & 5 & 1565 \\
Femur & 17 & 15 & 2 & 594 \\
Tibia & 2 & 1 & 1 & 501 \\
Humerus & 5 & 5 & 0 & 374 \\
Overall & 42 & 32 & 10 & 981 \\
\hline
\end{tabular}

4 alive), followed by lung tumors ( 7 cases, 6 dead and 1 alive), prostate tumors ( 6 cases, all dead) and thyroid (5 cases, 2 dead and 3 alive). Other tumors comprised 16 cases (14 dead and 2 alive). Patients with breast tumors had the longest survival time (mean 43.3 months), followed by thyroid (25.1 months), prostate (21.5 months), and lung (17.4 months, the shortest survival times); however, no significant differences were found $(P>0.05)$.

Table 4- Days of survival by primary tumor site

\begin{tabular}{lcccc}
\hline $\begin{array}{l}\text { Primary } \\
\text { tumor site }\end{array}$ & Total & Alive & Dead & $\begin{array}{c}\text { Average of } \\
\text { Survival }\end{array}$ \\
\hline Breast & 9 & 5 & 4 & 1300 \\
Prostate & 6 & 6 & 0 & 646 \\
Lung & 7 & 6 & 1 & 525 \\
Thyroid & 5 & 2 & 3 & 753 \\
Other & 16 & 14 & 2 & 755 \\
Overall & 43 & 33 & 10 & 970 \\
\hline
\end{tabular}

\section{Non-bone metastasis}

The 11 cases with non-bone metastases had survival times of 32 months. The 32 cases without non-bone metastases had a mean survival time of 28.4 months. There was no significant difference between these mean survival times $(P>0.05)$ (Table 5).

Table 5- Days of survival by presence of non-bone metastasis

\begin{tabular}{lcccc}
\hline $\begin{array}{l}\text { Non-bone } \\
\text { metatasis }\end{array}$ & Total & Alive & Dead & $\begin{array}{c}\text { Average days } \\
\text { of survival }\end{array}$ \\
\hline No & 32 & 24 & 8 & 853 \\
Yes & 11 & 9 & 2 & 962 \\
Overall & 43 & 33 & 10 & 970 \\
\hline
\end{tabular}

\section{Treatment type}

Of the 43 patients, 16 underwent exclusively clinical treatments. Eleven of them died and 5 are alive. Twentyseven patients underwent clinical and surgical treatment; 22 died and 5 are alive. Longer survival times (Table 6) 
were observed among clinically treated patients (mean: 34.1 months). Those surgically treated had a survival time of 28.3 months. There were no significant differences between these mean survival times $(P>0.05)$.

Table 6- Days of survival by type of treatment: surgical vs clinical

\begin{tabular}{lcccc}
\hline $\begin{array}{l}\text { Treatment } \\
\text { type }\end{array}$ & Total & Alive & Dead & $\begin{array}{c}\text { Average day } \\
\text { of survival }\end{array}$ \\
\hline Surgical & 27 & 22 & 5 & 850 \\
Clinical & 16 & 11 & 5 & 1025 \\
Overall & 43 & 33 & 10 & 970 \\
\hline
\end{tabular}

\section{Surgical type}

Regarding surgically treated patients (Tables 7 and 8; Figure 7), 16 had endoprostheses (14 dead, 2 alive); 9 had osteosynthesis (6 dead, 3 alive); 1 had an amputation (dead); and 1 had an external fixator (dead). Patients treated with osteosynthesis had longer survival times (mean: 47.8 months), followed by endoprosthesis (21.6 months). These means were significantly different $(P<0.05)$.

Table 7- Days of survival by type of surgical treatment

\begin{tabular}{lcccc}
\hline Surgery & Total & Alive & Dead & $\begin{array}{c}\text { Average days } \\
\text { of survival }\end{array}$ \\
\hline Amputation & 1 & 1 & 0 & 19 \\
Endoprothesis & 16 & 14 & 2 & 648 \\
External Fixation & 1 & 1 & 0 & 22 \\
Osteosynthesis & 9 & 6 & 3 & 1435 \\
Overall & 27 & 22 & 5 & 850 \\
\hline
\end{tabular}

Table 8. Statistical analysis for the different types of surgery, as specified in Table 7.

\begin{tabular}{llll}
\hline & chi-square & df & $P$ \\
\hline Log Rank (Mantel-Cox) & 13.193 & 3 & 0.004 \\
Breslow (Generalized Wilcoxon) & 11.572 & 3 & 0.009 \\
Tarone-Ware & 12.284 & 3 & 0.006
\end{tabular}

\section{DISCUSSION}

Although we obtained survival data from only 43 of the 112 patients studied, it was important to analyze both groups, since the larger sample allows us to know whether the profile of patients treated at the Instutute of Orthpedics and Trauma of Hospital das Clínicas, São Paulo University Medical School is similar to that of the population studied in international literature. This allowed us to reduce our sample bias.

Based on the 112 patients, we observed an agreement

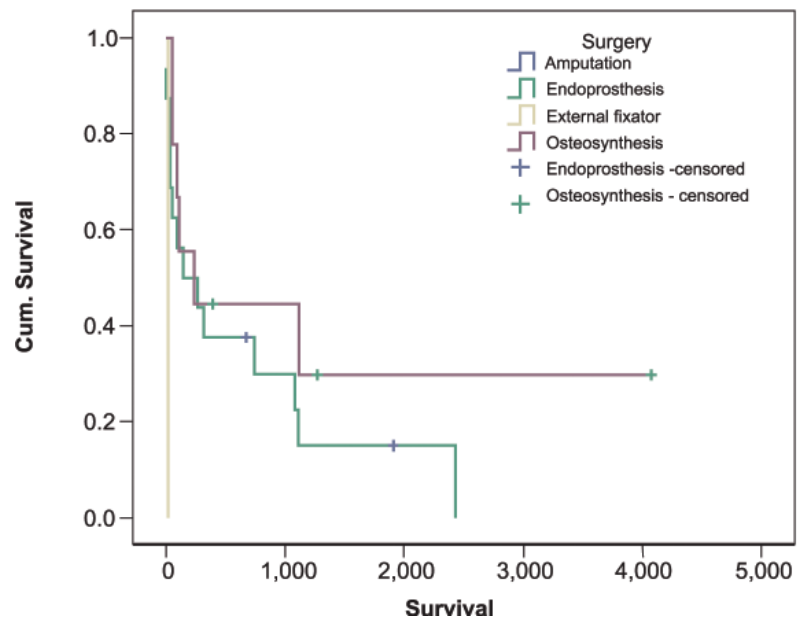

Figure 7 - Survival functions

with reported data in terms of incidence of primary tumors that metastasize mostly to the bone, ie, breast, prostate, lung, and thyroid primary tumors. ${ }^{12}$ The most affected age range was the $5^{\text {th }}$ decade. The incidence of diagnosed non-bone metastases was $15 \%$, the lung being the most common.

The most affected site in the patients treated in our Service were the lower limbs (47\%), more specifically the femur, and this differs from most reported studies. ${ }^{2,3}$ A possible explanation is that vertebral column fractures are less frequently referred to the Tumor Group of our Service and/ or they are underdiagnosed.

Surgical treatment was performed in most patients (59\%), although it is more indicated for pathological femoral and humeral fractures. Exclusively clinical treatment was the most indicated for pathological fractures of the vertebral column and pelvic girdle (41\%).

Among surgically treated patients, more endoprostheses were performed $(66 \%)$ than any other type of procedure because there was higher incidence of proximal femoral pathological fractures (44\%).

Currently, interlocking nails are preferred over endoprostheses in cases of proximal femoral pathological fractures, due to their lower morbidity in cases with less destruction of bone matrix. This procedure is invariably supplemented by postoperative radiotherapy. ${ }^{1,2,7}$

Hemoglobin was not a relevant datum in our study because only 1 patient in our sample had $\mathrm{Hb}<7 \mathrm{~g} / \mathrm{dL}$.

By analyzing the subgroup formed by 43 patients for whom survival data was available, we found that sex, age, primary tumor, site affected, non-bone metastasis, and clinical versus surgical treatment variables are not good predictors for survival. We found that the evidence of visceral metastasis in patients with pathological fractures does not necessarily mean a poorer prognosis, nor does the fracture site or the primary tumor. A possible explanation for this 
would be the fact that the fracture itself represents a strong determinant for survival decrease in this population.

However, the type of surgery performed was significantly associated with length of survival, which supported our hypothesis that surgery type would be the largest determinant of survival decrease in these cancer patients. Patients who received an endoprosthesis (mean survival time, 21.6 months) had worse prognoses than those undergoing osteosynthesis (mean survival time, 47.8 months). This may be explained either by the higher severity of proximal femoral fractures that were more frequently treated with endoprostheses, or by the fact that the surgical technique employed in osteosynthesis is less aggressive, produces less morbidity, and is more prone to rehabilitation than the technique involving an endoprosthesis.

\section{CONCLUSION}

We conclude that the treatment of choice for pathological diaphyseal femoral and proximal femoral fractures is internal fixation using interlocking medullary nailing, which is less aggressive to soft tissue and patients.

This is also shown by the current international literature $;^{1,2,7}$ the profile of the population in this study was similar to those in other studies. ${ }^{1,4,5,7-14}$

Whenever it can be indicated, osteosynthesis with interlocking nails for pathological fractures is more compatible with patients' survival, since it reduces hospital stay, rehabilitation time, surgical time and bleeding, and makes it possible to stabilize the entire femur, compared to endoprostheses. ${ }^{2,14}$

\section{RESUMO}

Narazaki DK, Alverga Neto CC, Baptista AM, Caiero MT, Camargo OP. Fatores prognósticos nas fraturas patológicas por tumores metastáticos.Clinics. 2006;61(4):313-20.

OBJETIVO: As fraturas patológicas por metástase óssea determinam uma queda abrupta na qualidade de vida dos pacientes com neoplasias malignas e também aumentam sua mortalidade. Os avanços ortopédicos de osteossíntese e endopróteses têm beneficiado a prevenção e tratamento dessas fraturas. O objetivo de nosso estudo é determinar quais são os fatores prognósticos dessas fraturas patológicas tratadas no nosso serviço.

CASUÍSTICA E MÉTODOS: Foram estudados 112 pacientes tratados com fraturas patológicas secundárias a tumores metastáticos entre abril de 1994 e dezembro de 2004, no nosso serviço. Os pacientes foram analisados 
quanto ao sexo, idade, local de metástase óssea, metástases viscerais, origem do tumor primário, tipo de tratamento, hemoglobina sérica e sobrevida.

RESULTADOS: O local mais acometido foi o fêmur (44\%), o tumor primário mais frequiente foi o câncer de mama $(25 \%)$, o tratamento cirúrgico mais realizado foi a endoprótese não convencional $(66 \%)$. As variáveis sexo, idade, tumor primário, local acometido, mestástase nãoóssea e tratamento clínico versus cirúrgico não são bons preditores para sobrevida. Os pacientes operados com endoprótese (21,6 meses) apresentaram pior prognóstico que os pacientes submetidos à osteossíntese (47,8 meses).
DISCUSSÃO E CONCLUSÃO: Os pacientes submetidos à osteossíntese, com uma técnica cirúrgica menos mórbida e de reabilitação mais precoce, apresentaram maior sobrevida em relação aos pacientes submetidos à endopróteses. Observamos que nossa casuística é semelhante à internacional, na qual aparece como tumor primário mais freqüente o de mama, os de origem indeterminada, próstata e pulmão.

UNITERMOS: Fraturas patológicas, Neoplasias, Metástases, Prognóstico, Cirurgia.

\section{REFERENCES}

1. Swanson KC, Pritchard DJ, Sim FH. Surgical treatment of metastatic disease of the femur. J Am Acad Orthop Surg. 2000;8:56-65.

2. Reich CD. Advances in the treatment of bone metastases. Clin J Oncol Nursing. 2003;7:641-6.

3. Cheng EY. Prospective quality of life research in bony metastatic disease. Clin Orthop. 2003;415(Suppl):289-97.

4. Habermann ET, Lopez RA. Metastatic disease of bone and treatment of pathological fractures. Orthop Clin North Am. 1989;20:469-86.

5. Kelly CM, Wilkins RM, Eckardt JJ, Ward WG. Treatment of metastatic disease of the tibia. Clin Orthop. 2003; 415(Suppl):219-29.
6. Wedin R, Bauer HC, Rutqvist LE. Surgical treatment for skeletal breast cancer metastases: a population-based study of 641 patients. Cancer. 2001;92:257-62.

7. Bocchi L, Lazzeroni L, Maggi M. The surgical treatment of metastases in long bones. Ital J Orthop Traumatol. 1988;14:167-73.

8. Buggay D, Jaffe K. Metastatic bone tumors of the pelvis and lower extremity. J Surg Orthop Adv. 2003;12:192-9.

9. Durr HR, Muller PE, Lenz T, Baur A, Jansson V, Refior HJ. Surgical treatment of bone metastases in patients with breast cancer. Clin Orthop. 2002;396:191-6. 
10. Althausen P, Althausen A, Jennings LC, Mankin HJ. Prognostic factors and surgical treatment of osseous metastases secondary to renal cell carcinoma. Cancer 1997;80:1103-9.

11. Iwamoto Y, Sugioka Y, Chuman H, Shiba K, Yuge I. Surgical treatment of metastatic tumors of long bones and the spine. Adv Exp Med Biol. 1992;324:295-303.

12. [No authors listed]. British Association of Surgical Oncology Guidelines. The management of metastatic bone disease in the United Kingdom. The Breast Specialty Group of the British Association of Surgical Oncology. Eur J Surg Oncol. 1999;25:3-23.
13. Schmidt RG. Management of extremity metastatic bone cancer. Curr Probl Cancer. 1995;19:166-82.

14. Weber KL, Lewis VO, Randall RL, Lee AK, Springfield D. An approach to themanagement of the patient with metastatic bone disease. Instr Course Lect. 2004; 53:663-76.

15. Van der Linden YM, Dijkstra PDS, Kroon HM, Lok JJ, Noordijk EM, Leer JWH, et al. Comparative analysis of risk factors for pathological fracture with femoral metastases. Results based on a randomised trial of radiotherapy. J Bone Joint Surg Br. 2004;86:566-73. 